\title{
Internalisasi nilai-nilai kewirausahaan Etnis Madura
}

\author{
Khofifatu Rohmah Adi* \\ Fakultas Ilmu Sosial Universitas Negeri Malang \\ khofifatu.rohmah.fis@um.ac.id \\ Idris \\ Fakultas Ilmu Sosial Universitas Negeri Malang \\ idris.fis@um.ac.id \\ Fatiya Rosyida \\ Fakultas Ilmu Sosial Universitas Negeri Malang \\ rosyida.fis@um.ac.id
}

\begin{abstract}
Madurese is an ethnic group that we encounter in many cities. This ethnicity is usually attached to the image of the merchant. Besides this image, Madura also attaches to the image of newcomers. How this ethnic group became very attached to the merchant's identity indeed cannot be separated from the role of parents. The family environment is very instrumental in directing or learning children. The purpose of this research is to find out how to internalize these ethnic entrepreneurial values-this research designed using a qualitative approach. Data collection techniques are done through observation and in-depth interviews. Interview techniques are used to reveal how to internalize the value of entrepreneurship towards families, especially children. The research findings show that in some ethnic Madurese, there is no internalization process of entrepreneurial values in their families, but in other parts, this process occurs. Furthermore, the findings in the field show that the experience of parents influences the internalization process. The process of internalizing entrepreneurial values did by modeling or giving examples by parents, involvement, and habituation of parents' activities to children. Involvement did and verbally begins by inviting children to help with the work of parents. Most entrepreneurs tend to learn from the experience of joining parents or family. The values adopted by children in this ethnicity are self-confidence, high work ethic.
\end{abstract}

Keywords: entrepreneurial value; Madurese ethnicity

\begin{abstract}
Abstrak
Etnis Madura merupakan etnis yang banyak kita jumpai di banyak kota. etnis ini biasanya lekat dengan citra pedagang. Selain citra tersebut Madura juga lekat dengan citra pendatang. Bagaimana etnis ini menjadi sangat lekat dengan identitas pedagang tentu tidak lepas dari peran orang tua. Lingkungan keluarga sangat berperan dalam mengarahkan atau membelajarkan anak-anak. Tujuan dilakukannya penelitian ini adalah untuk mengetahui bagaimana internalisasi nilai-nilai kewirausahaan etnis ini. Penelitian ini dirancang dengan menggunakan pendekatan kualitatif. Teknik pengumpulan data dilakukan dengan observasi dan wawancara
\end{abstract}

* Korespondensi penulis 


\section{Khofifatu Rohma Adi, Idris, dan Fatiya Rosyida}

secara mendalam. Teknik wawancara digunakan untuk mengungkap bagaimana internalisasi nilai kewirausahaan terhadap keluarga khususnya anak-anak. Temuan penelitian menunjukkan bahwa pada sebagian Etnis Madura, tidak terjadi proses internalisasi nilai kewirausahaan pada keluarganya, namun pada sebagian yang lain proses ini terjadi. Lebih lanjut, temuan di lapangan menunjukkan bahwa terjadi tidaknya proses internalisasi dipengaruhi pengalaman dari orang tua. Proses internalisasi nilai-nilai kewirausahaan dilakukan dengan modeling atau pemberian contoh oleh orang tua, pelibatan dan pembiasaan aktivitas orang tua kepada anakanak. Pelibatan dilakukan dan dimulai secara verbal dengan mengajak anak-anak untuk turut membantu pekerjaan orang tua. Sebagian besar wirausahawan cenderung belajar dari pengalaman ikut orang tua atau keluarga. Nilai-nilai yang diadopsi oleh anak-anak pada etnis ini adalah rasa percaya diri, etos kerja yang tinggi.

Kata Kunci: Nilai kewirausahaan; Etnis Madura

Diterima 12 Februari 2020, Dipublikasikan 30 April 2020

\section{PENDAHULUAN}

Indonesia merupakan negara yang memiliki banyak suku dan etnis budaya. Salah satu etnis yang lekat dengan perantauan dan dunia usaha adalah Etnis Madura. Lekatnya dunia usaha dengan etnis ini didukung dengan karakteristik yang melekat dari etnis Madura yakni sikap ulet dan pantang menyerah. Etnis Madura bahkan dikatakan layak menjadi ikon perkembangan bisnis kelas menengah ke bawah di Indonesia (Djakfar, 2009).

Etnis Madura memiliki sikap bekerja keras, jujur dan ramah dalam berdagang dan pantang menyerah (Faraby, 2014). Sikap yang dimiliki etnis Madura tersebut merupakan faktor yang sangat penting untuk dimiliki oleh seorang entrepreneur. Tanpa adanya faktor ini maka usaha yang digeluti sulit berhasil. Selain sikap-sikap tersebut, etnis Madura memiliki karakteristik lain yaitu rajin, cekatan dan penuh prakarsa (Rifai, 2007). Sikap dan karakter tersebut tentu tidak dimiliki secara instan akan tetapi sikap tersebut dari genetik atau terpola karena situs sosial budaya yang melingkupi kehidupan mereka sehari hari, atau bisa juga karena keduanya (Faraby, 2014)

Etnis Madura berasal dari daerah yang memiliki nama yang sama dengan nama etnisnya, yakni pulau Madura. Pulau Madura terletak di Provinsi Jawa Timur, tepatnya terletak di sebelah timur laut pulau Jawa, namun realitasnya kita tidak hanya bisa bertemu etnis Madura di pulau tersebut tetapi, dibanyak kota di Jawa Timur kita dapat menemui etnis ini. Banyaknya masyarakat Madura yang melakukan migrasi ke daerah lain disebabkan oleh kemiskinan (Hartono, 2010). Tujuan dari migrasi yang dilakukan oleh masyarakat Madura tidak lain adalah untuk memperbaiki taraf kehidupan. untuk mencapai tujuan tersebut, mereka memilih berdagang. Di Kota malang, etnis ini menduduki peringkat dua dalam komposisi kesukuan yang ada dalam suatu wilayah (PODES, 2018), dan mayoritas penghasilan utama didapatkan dari sektor niaga (BPS, 2019), lebih tepatnya wirausaha.

Sebagai pendatang upaya untuk mempertahankan diri tentu jauh lebih berat dibanding dengan penduduk asli. Hal ini tak lain karena ketika seseorang menjadi pendatang mereka 


\section{Internalisasi nilai-nilai kewirausahaan Etnis Madura}

harus berjuang dari nol, dan memulai semua usaha dari awal. Dengan tantangan yang jauh lebih berat seperti itu tentu segala upaya, nilai-nilai yang dianut serta sikap yang dimiliki akan ditularkan atau akan ditanamkan kepada anak cucu mereka, dengan harapan anak cucu mereka kelak jauh lebih siap dan mantab menghadapi persaingan dunia luar.

Definisi kewirausahaan mengalami perkembangan seiring dengan perkembangan waktu, dan sebagian besar definisi-definisi yang kita kenal mengacu pada konsep kewirausahaan yang diutarakan oleh Schumpeter. Pada intinya kewirausahaan identik dengan adanya inovasi. Rusdiana (2018) menyatakan bahwa substansi kewirausahaan adalah proses penciptaan suatu yang berbeda nilainya dengan menggunakan usaha dan waktu yang diperlukan, memikul risiko finansial, psikologi, dan sosial yang menyertainya, serta menerima balas jasa moneter dan kepuasan pribadi. Suryana, dkk. (2011) menyebut bahwa kewirausahaan merupakan seseorang yang memiliki kreativitas suatu bisnis baru dengan berani menanggung risiko dan ketidakpastian yang bertujuan untuk mencari laba dan pertumbuhan usaha berdasarkan identifikasi peluang dan mampu mendayagunakan sumber-sumber serta memodali peluang ini. Kewirausahaan merupakan suatu upaya dalam mendayagunakan sumber daya dengan kreativitas serta inovasi yang dimiliki dalam rangka mengambil peluang untuk memperoleh balas jasa moneter serta kepuasan (Al Siddiq et al., 2020; Purwadita et al., 2018; Sani et al., 2018).

Internalisasi nilai merupakan suatu proses yang sangat mendalam dalam rangka menanamkan nilai-nilai dalam diri seseorang. Thoha (2006) menjelaskan bahwa internalisasi nilai merupakan teknik dalam Pendidikan nilai yang sasarannya sampai pada pemilikan nilai yang menyatu dalam kepribadian peserta didik. Lebih lanjut Utomo (2017) menjelaskan bahwa internalisasi nilai merupakan suatu yang sangat penting dalam pembelajaran, hal ini dikarenakan melalui proses internalisasi nilai peserta didik (anak-anak) dapat mewujudkan suasana yang kondusif dalam belajar.

Pendidikan kewirausahaan merupakan pendidikan yang menanamkan nilai-nilai kewirausahaan, tidak saja dalam pendidikan di sekolah akan tetapi pendidikan kewirausahaan dapat pula diberikan pada lingkungan keluarga. Hal ini sesuai dengan yang dikatakan Winarno (2009) yang menyatakan bahwa Pendidikan yang berbasis kewirausahaan merupakan Pendidikan yang menerapkan prinsip-prinsip dan metodologi ke arah internalisasi nilai-nilai yang menggunakan model dan strategi pembelajaran yang sesuai dengan tujuan pembelajaran. Pendidikan dilingkungan keluarga merupakan Pendidikan dasar dan paling awal yang diterima oleh anak-anak. Hal ini tidak lain karena keluarga merupakan lingkungan pertama yang dikenal oleh anak. Lingkungan keluarga juga sekaligus menjadi sekolah pertama bagi anak-anak. Nilainilai yang dianut oleh keluarga (orang tua) baik secara langsung maupun tidak langsung ditularkan atau diajarkan dalam lingkungan ini. Proses belajar anak diawali dengan cara mengamati dan meniru perilaku yang dilakukan oleh orang tua. Selain itu lebih lanjut dan lebih dalam lagi anak-anak dapat dilibatkan dalam kegiatan sehari-hari. 


\section{Khofifatu Rohma Adi, Idris, dan Fatiya Rosyida}

Seseorang yang memiliki jiwa wirausaha memiliki jiwa pantang menyerah, kreatif dan inovatif, rasa percaya diri yang tinggi. Sebagaimana yang diungkapkan oleh Kuratko (2003) bahwa seseorang yang memiliki jiwa wirausaha memiliki kepribadian yang memiliki tindakan kreatif sebagai nilai, gemar berusaha, tegar dalam menghadapi tantangan, percaya diri, memiliki self determination atau locus of control, berkemampuan mengelola risiko, perubahan dipandang sebagai peluang, toleransi terhadap banyaknya pilihan, inisiatif dan memiliki need of achievement, perfectsionis, berpandangan luas, menganggap waktu sangat berharga serta memiliki motivasi yang kuat, dan nilai-nilai itu telah menginternal sebagai nilai-nilai yang dianggap benar. Suryana (2006) menambahkan ada 6 nilai hakiki dan penting dari kewirausahaan, yakni: percaya diri, berorientasi pada tugas dan hasil, keberanian mengambil risiko, kepemimpinan, berorientasi ke masa depan, dan keaslian (kreativitas dan inovasi).

Nilai-nilai kewirausahaan sangat penting dan perlu untuk ditanamkan kepada anakanak. Hal ini karena kewirausahaan adalah salah satu kunci dari perkembangan perekonomian suatu bangsa. Jika anak-anak dari awal sudah diajarkan tentang kewirausahaan maka akan mendorong anak-anak untuk tertarik dengan dunia wirausaha. Sehingga dengan demikian generasi penerus bangsa kan tumbuh menjadi generasi-generasi pejuang yang mampu berdiri dan menciptakan usahanya sendiri-sendiri.

\section{METODE}

Penelitian ini menggunakan pendekatan kualitatif. Etnis Madura dan China dipilih sebagai sasaran penelitian atas dasar pertimbangan, bahwa kedua etnis tersebut merupakan pelaku bisnis yang ulet dan pantang menyerah. Metode pengumpulan data yang digunakan untuk menggali informasi menggunakan observasi, wawancara, dan dokumentasi. Namun teknik yang paling dominan adalah teknik wawancara. Teknik ini dilakukan untuk mengungkap bagaimana proses internalisasi nilai-nilai kewirausahaan terhadap keluarga khususnya anak-anak, pada etnis Madura dan China. Sedangkan observasi sebatas digunakan untuk mengamati aktivitas bisnis dalam realitas. Informan yang dijadikan sumber data adalah para pedagang perantauan dari Etnis Madura di Kota Malang dengan menggunakan purposive sampling sesuai dengan kebutuhan agar lebih alami dalam memahami bagaimana proses internalisasi di kalangan mereka sesuai dengan tujuan penelitian. Metode analisis data yang dipakai dalam penelitian ini mengadaptasi model analisis data Miles and Huberman (1994) antara lain kegiatan reduksi data, penyajian data, dan penarikan kesimpulan dan verifikasi yang dipadukan dengan analisis dari teori kognisi sosial (Vygotsky, 1980).

\section{HASIL DAN PEMBAHASAN}

Pembelajaran kognisi sosial yang dicetuskan oleh Vygotsky meyakini bahwa kebudayaan merupakan penentu utama bagi perkembangan individu. Lebih jauh Suyono (2014) mengatakan bahwa perkembangan pembelajaran anak dipengaruhi banyak atau sedikitnya dari kebudayaan yang dimilikinya, termasuk kebudayaan dari lingkungan 


\section{Internalisasi nilai-nilai kewirausahaan Etnis Madura}

keluarganya, di mana mereka berkembang. Dalam teori kognisi sosial yang dikemukakan oleh Vygotsky salah satu pokok kunci pemikirannya mengatakan bahwa internalisasi mengacu kepada proses pembelajaran, yang mana dalam melakukan internalisasi kebudayaan yang kaya akan pengetahuan yang berada pada luar diri anak, berlangsung melalui Bahasa.

Lingkungan keluarga merupakan tempat yang sebagian besar anak-anak lewati untuk berinteraksi. Melalui keluarga edukasi terjadi dalam interaksi yang terjadi di dalamnya. Nilainilai yang dianut oleh anak-anak diajarkan atau ditularkan baik secara sadar maupun tidak sadar melalui kegiatan-kegiatan yang dilakukan bersama. Upaya yang dapat dilakukan orang tua dalam menumbuhkan motivasi kewirausahaan anak-anak dapat dilakukan secara verbal dan dengan pelibatan anak dalam berbagai kegiatan ekonomi keluarga yang akan menimbulkan persepsi positif dan pada akhirnya akan menimbulkan motivasi kewirausahaan (Majdi, 2012). Sebagaimana yang diungkapkan oleh Bongsu, bahwa pendidikan dilingkungan keluarga berpengaruh positif terhadap motivasi untuk berwirausaha (Bongsu Hutagalung, 2017). Selain itu sebagian besar wirausahawan cenderung belajar dari pengalaman ikut orang tua atau keluarga (Fathorahman, 2011)

Proses internalisasi yang dilakukan oleh masyarakat Etnis Madura, yang saat ini berusia sekitar 60 sampai 70 tahunan, mereka mengatakan bahwa zaman dahulu orang tua mengenalkan pekerjaan yang digeluti orang tua mereka dengan mengajak anak-anak untuk membantu pekerjaannya (berdagang). Dengan terlibat pada pekerjaan orang tua secara tak sadar mereka dilatih untuk percaya diri, dan menerima seperti apa pekerjaan orang tua mereka. Pelibatan anak-anak dalam pekerjaan yang dilakukan orang tua juga merupakan suatu bentuk pendidikan yang dilakukan orang tua terhadap anak-anak. Ki Hajar Dewantoro menyebut bahwa orang tua berperan sebagai guru dan panutan, sebagai pengajar, sebagai contoh dan teladan bagi anak-anak (Jailani, 2014). Apa yang dilakukan dan diajarkan oleh orang tuanya zaman dahulu, merupakan refleksi orang tua sebagai guru, pengajar, bahkan sebagai contoh dan teladan bagi anak-anaknya saat ini.

Interaksi yang terjadi dalam lingkungan keluarga merupakan pendidikan awal yang dikenal oleh anak-anak. proses ini berlangsung secara pelan tapi pasti melalui pembiasaanpembiasaan yang dilakukan oleh keluarga, sehingga pembiasaan yang dilakukan ini pada akhirnya akan mempengaruhi, persepsi, sikap dan perilaku anak-anak. sejalan dengan hal ini Choueke dan Amstrong (1988) menyebutkan bahwa Pendidikan memiliki tujuh fungsi sosial Pendidikan yakni (1) pengajar ketrampilan, (2) mentransmisikan budaya, (3) mendorong adaptasi lingkungan, (4) membentuk kedisiplinan, (5) mendorong bekerja kelompok, (6) meningkatkan perilaku etik, dan yang terakhir (7) memilih bakat dan memberi penghargaan prestasi.

Pendidikan dalam lingkungan keluarga dapat membuat anak menjadi terampil melakukan sesuatu seperti yang diungkapkan oleh Chouke dan Amstrong tersebut. Ketika dahulu orang tua mengajak untuk membantu berdagang, kemudian mereka mencontoh, sehingga kemudian saat ini pengalaman tersebut mereka gunakan untuk melakukan pekerjaan 


\section{Khofifatu Rohma Adi, Idris, dan Fatiya Rosyida}

mereka saat ini. Pendidikan dalam lingkungan keluarga membekali anak-anak untuk bekal dalam hidup bermasyarakat serta mengembangkan potensi yang dimiliki anak-anak (Dewantara, 1961; Jailani, 2014). Selain itu sikap bekerja keras yang ditampilkan dalam citra keluarga dalam bentuk menggeluti profesinya, pada akhirnya ditransmisikan pada anakanaknya lagi, sehingga anak-anak mereka yang telah dewasa saat ini memiliki sikap ulet dan percaya diri dalam bekerja.

Nilai yang belum terlihat oleh etnis ini adalah nilai keberanian mengambil risiko. sebagai buktinya bahwa belum adanya usaha-usaha baru yang dilakukan secara mandiri oleh anak-anak pada Etnis Madura. Sebagian besar usaha yang digeluti saat ini tidak jauh berbeda dengan usaha orang tuanya terdahulu, atau belum ada inovasi dalam hal usaha yang mereka geluti. meskipun demikian semangat kerja dan etos kerja yang tinggi mampu tercermin oleh sikap mereka yang mau bekerja apa saja untuk memperoleh sumber penghidupan.

Proses internalisasi nilai kewirausahaan ternyata tidak selalu dilakukan oleh keluarga pada Etnis Madura. Temuan di lapangan menunjukkan bahwa internalisasi dilakukan pada sebagian pedagang etnis ini. Adanya proses internalisasi ternyata dipengaruhi oleh usia pedagang saat ini, di mana pengalaman pedagang turut berperan dalam adanya proses internalisasi. Latar belakang orang tua yang juga pedagang turut mempengaruhi bagaimana mereka saat ini. Hal ini selaras dengan yang diungkapkan oleh Suyono bahwa banyak sedikitnya kebudayaan yang dimiliki turut mempengaruhi internalisasi berlangsung. Nilai-nilai yang mereka miliki saat ini adalah hasil internalisasi dengan orang tua terdahulu. Selain itu faktor kuantitas waktu interaksi yang dimiliki antara orang tua dan anak juga diduga turut berperan dalam proses internalisasi.

Teori strategi internalisasi nilai yang popular pada kalangan pendidik seperti yang diungkapkan oleh Munif (2017) meliputi keteladanan, pembiasaan, mengambil pelajaran dan perumpamaan, pemberian nasehat, pemberian janji dan ancaman, strategi kedisiplinan. Strategi pertama yang dapat dilakukan dalam rangka internalisasi nilai adalah pemberian contoh atau keteladanan secara konkret. Artinya orang tua dapat memberi contoh melalui kegiatan mereka sehari-hari. Akan tetapi keteladanan ini dapat sangat melekat erat jika dibarengi dengan strategi pembiasaan. Pembiasaan merupakan kegiatan yang dilakukan secara berulang-ulang. Mengambil pelajaran dan perumpamaan biasanya dapat dilakukan dengan mengambil pelajaran dari kisah orang yang sukses. Strategi pemberian nasehat adalah pemberian peringatan atas kebaikan dan kebenaran. Pemberian janji dan ancaman, adalah bujukan dalam rangka anak-anak melakukan suatu kebaikan. Sedangkan kedisiplinan adalah ketegasan orang tua dalam mendidik anak-anaknya. Dari sebagian besar cara atau strategi yang biasa dilakukan dalam rangka internalisasi tersebut, perlu dilakukan dengan interaksi secara langsung, dengan diberi penjelasan. Strategi-strategi seperti keteladanan dan pembiasaan, diterapkan oleh sebagian wirausaha Madura.

Pada sebagian Etnis Madura yang lain, yang saat ini berusia sekitar 40 sampai dengan 50 tahun, dengan latar belakang orang tua yang beda profesi (bukan pedagang). Internalisasi 


\section{Internalisasi nilai-nilai kewirausahaan Etnis Madura}

nilai kewirausahaan pada anak-anak tidak terjadi. Anak-anak pedagang Etnis Madura pada usia ini rata-rata memiliki anak usia sekolah, yakni usia SD. Hal-hal yang dilakukan orang tua mereka saat ini belum bisa mereka jadikan contoh. Hal ini karena anak-anak pada usia mereka harus diberi penjelasan dan contoh secara konkret. Sebagaimana teori yang diungkapkan oleh Piaget (dalam Samani, 2014) bahwa anak-anak pada usia tersebut berada pada tahap operasi konkret yang mana pada tahap ini anak-anak belum sepenuhnya menyadari prinsip atau makna apa yang terkandung dalam apa yang mereka lihat, dengan kata lain mereka tahu sesuatu namun mereka tahu tanpa menggunakan pemikiran rasional. Selain itu tanpa adanya pelibatan anak-anak pada aktivitas orang tua juga merupakan bukti bahwa belum ada usaha dalam hal mempengaruhi anak untuk bertindak ke arah tertentu. Sebagaimana yang diungkapkan oleh Steinberg et al (1996) yang menyatakan bahwa orang tua memiliki pengaruh yang sangat besar untuk mengarahkan anak-anak mereka dengan cara yang positif, yang dapat dilakukan dengan melibatkan mereka dalam aktivitas. Misalnya orang tua ingin anak-anaknya mengenal wirausaha maka mereka harus melibatkan anak-anak pada aktivitas yang berkaitan dengan wirausaha.

\section{SIMPULAN}

Kesimpulan yang diperoleh dari penelitian ini adalah pada sebagian etnis Madura, Internalisasi nilai kewirausahaan dilakukan dengan keteladanan dan pelibatan serta pembiasaan kepada anak-anak. Pada sebagian etnis Madura yang lain belum ada internalisasi karena hal yang dilakukan oleh orang tua (menjalani pekerjaannya sebagai pedagang) belum bisa dijadikan teladan karena usia anak yang relatif kecil sehingga kapasitas berpikir belum mampu mencapainya. Nilai kewirausahaan yang tampak pada wirausaha etnis Madura adalah ulet, percaya diri dalam bekerja, semangat kerja dan etos kerja yang tinggi sebagaimana tercermin dalam perilaku berwirausaha mereka.

Dalam riset ini, penelitian hanya difokuskan pada pola kewirausahaan yang dikembangkan pada Etnis Madura di Kota Malang. Batasan ini didasarkan pada fenomena pelaku wirausaha kecil seperti pedagang tanpa toko yang mayoritas merupakan Etnis Madura. Dari hasil temuan, internalisasi dilakukan melalui cara pembiasaan sehingga pada usia dini nilai kewirausahaan belum tergambar jelas. Oleh karena itu direkomendasikan kajian mendalam pada pengaruh pada pembiasaan yang dilakukan terhadap pengetahuan berwirausaha.

\section{DAFTAR PUSTAKA}

Al Siddiq, I.H., Winarno, A., Idris, Ridhoi, R., 2020. Encouraging Economic Development Through Local Community Participation in Sidoarjo, Indonesia, in: Proceedings of the International Conference on Social Studies and Environmental Issues (ICOSSEI 2019). Presented at the Proceedings of the International Conference on Social Studies and Environmental Issues (ICOSSEI 2019), Atlantis Press, Kota Malang, Indonesia. https://doi.org/10.2991/assehr.k.200214.022 


\section{Khofifatu Rohma Adi, Idris, dan Fatiya Rosyida}

Bongsu Hutagalung, D. M. (2017). The Effect of Enterpreneurship Education and Family Environment. International Journal of Economic Research, 331.

BPS Kota Malang. (2019). Kota Malang Dalam Angka tahun 2019. Malang: Badan Pusat Statistik

Choueke, dan Amstrong. (1988). The Learning Organization in Small and Medium-size Enterprises, A destination or a journey. International Journal of Entrepreneurial Behavior \& Research. Vol.4 (2),129-140.

Dewantara, Ki Hajar. (1961). Ilmu Pendidikan. Yogyakarta: Taman Siswa

Djakfar, Muhammad. (2009). Anatomi Pelaku Bisnis Dialektika Etika dengan Realitas. Malang: UIN Malang Press

Faraby, Muhammad Ersya. (2014). Etos Kerja Pedagang Etnis Madura di Pusat Grosir Surabaya ditinjau dari Etika Bisnis Islam. JESTT. Vol. 1 No. 3 Maret 2014

Fathorahman. (2011). Analisis Model Perilaku Wirausaha Masyarakat Madura dan Orientasi Nilai-Nilai Kesuksesan Anak. Prosiding Universitas Wiraraja Sumenep

Hartono, Mudji. (2010). Migrasi orang-orang madura di Ujung Timur Jawa Timur: Suatu Kajian Sosial Ekonomi. ISTORIA. Volume VIII BNomor 1 September 2010

Jailani, M. Syahran. (2014). Teori Pendidikan Keluarga dan Tanggung Jawab Orang Tua dalam Pendidikan Anak Usia Dini. Nadwa: Jurnal Pendidikan Islam. Vol 8 No 2 Oktober 2014 hal 245-260

Majdi, Muhammad Zainul. (2012). Pengaruh Pembelajaran Kewirausahaan, Internalisassi Nilai Kewirausahaan di Keluarga dan Motivasi Minat kewirausahaan. Jurnal Educatio. Vol 7 no 2 desember 2012 halaman 1-25

Kuratko, D.F. (2003). Entrepreneurship Education: Emergin Trends and challenger for the 21 centure. The entrepreneurship program,dkuratko @bsu.edu

Miles, M., \& Huberman, M. (1994). Qualitative Data Analysis: An Expanded sourcebook (2 ${ }^{\text {nd }}$ ed). LA, USA:Thousand oak, CA Sage

Munif, Muhammad. (2017). Strategi Internalisasi Nilai-Nilai Dalam Pembentukan Karakter Siswa. Edureligia Vol.01 No Tahun 2017

PODES Kota Malang. (2018). Jakarta: Badan Pusat Statistik

Purwadita, C.P., Sudiro, A., Mugiono, M., Idris, I., 2018. Innovation in leadership and team performance: Evidence from indonesia property agent industry. Management and Economics Journal (MEC-J), 2, 133-151. http://dx.doi.org/10.18860/mec-j.v0i1.5221

Rifai, Mien Ahmad. (2007). Manusia Madura. Yogyakarta: pilar media

Rusdiana. (2018). Kewirausahaan: Teori dan Praktik. Bandung: Pustaka Setia

Samani, Muchlas. (2014). Belajar dan Pembelajaran. PT Remaja Rosdakarya: Bandung

Sani, A., Ekowati, VM., Wekke, I.S., Idris, I., 2018. Respective contribution of entrepreneurial leadership through organizational citizenship behavior In creating employees performance. Academy of Entrepreneurship Journal 24, 1-11.

Steinberg, L., Brown, B.B., \& Dornbusch,S.M. (1996) Beyond The Classroom: Why School reform has failed and what parents need to do. New York: Simon\&Schuster

Suryana. (2006). Kewirausahaan: Pedoman praktis, Kiat dan Proses menuju Sukses. Jakarta: Salemba Empat. 


\section{Internalisasi nilai-nilai kewirausahaan Etnis Madura}

Suryana, Yuyus. (2011). Kewirausahaan: Pendekatan Karakteristik Wirausahawan Sukses. Jakarta: Kencana

Suyono dan Hariyono. (2014). Belajar dan Pembelajaran. Bandung: PT Remaja Rosda karya Thoha, Chabib. (2006). Kapita selekta Pendidikan islam. Jogjakarta: Pustaka pelajar.

Utomo, Sigit ari. Dan Ahmad sa'i. (2017). Internalisasi nilai-nilai akhlaqul karimah siswa pada pembelajaran akidah akhlaq di MI Kec Winusasi Kab. Magelang. Jurnal penelitian Vol 11 No. 1 Februari $2017 \mathrm{ss}$

Winarno, Agung. (2009). Pengembangan Model Pembelajaran Internalisasi Nilai-Nilai Kewirausahaan pada Sekolah Menengah Kejuruan di Kota Malang. Jurnal Ekonomi Bisnis. Tahun 14 Nomor 2 Juli 2009

Vygotsky, L. S. (1980). Mind in society: The development of higher psychological processes. Harvard university press 